\title{
Emotional Intelligence of Local and Overseas Graduates in Real Estate Industry in China
}

\author{
Leshui Zhang and *Riza Yosia Sunindijo
}

\begin{abstract}
First submission: 6 March 2020; Accepted: 23 August 2020; Published: 30 July 2021
To cite this article: Leshui Zhang and Riza Yosia Sunindijo (2021). Emotional intelligence of local and overseas graduates in real estate industry in China. Journal of Construction in Developing Countries, 26(1): 185-204. https://doi.org/10.21315/ jcdc2021.26.1.9.
\end{abstract}

To link to this article: https://doi.org/10.21315/jcdc2021.26.1.9

\begin{abstract}
There is still limited research that investigates emotional intelligence in the context of the real estate sector in China, despite the rapid growth of the industry. Furthermore, there has been an exponential increase in the number of Chinese students studying overseas. Underpinned by these tendencies, this research investigates the levels of emotional intelligence of overseas and local graduates in the real estate sector in China. Data were collected using a survey of 140 employees and semi-structured interviews of four human resource managers in six Grade One state-owned real estate companies in China. The findings suggest that emotional intelligence influences the levels of interpersonal skills, represented by communication skills and teamwork behaviour. However, there is no difference in the levels of emotional intelligence between overseas and local graduates, suggesting that there are other factors that influence emotional intelligence development. Overseas graduates also seem to have greater difficulties than local graduates from elite universities to find jobs in the real estate sector. This suggests that international study experience is no longer adequate; instead, various contextualised interpersonal skills are needed to meet work demands in China. Developing emotional intelligence has been found to promote success across cultures and is a way to meet the demands of today's work environments in the real estate industry in China.
\end{abstract}

Keywords: China, Emotional intelligence, Communication skills, Teamwork behaviour, Interpersonal skills, Real estate, Overseas graduates

\section{INTRODUCTION}

The real estate industry in China is growing rapidly due to high market demands and healthy economic growth. Along with this growth, there is a need for real estate companies in China to interact with clients and stakeholders who have diverse languages and cultural backgrounds. Not only requiring a fresh influx of employees to meet workflow demands, these companies also seek to hire employees with overseas education to operate in a business environment that is becoming more and more globalised. Furthermore, in a world that is becoming increasingly interconnected, interpersonal skills also have become a major factor that determines employee success in China (Lu and Guy, 2018). Most employers expect their employees to possess many facets of interpersonal skills, such as emotional intelligence (EI) (Sunindijo and Hadikusumo, 2014), teamwork (Pant and Baroudi, 2008), integrity (Robles, 2012), problem solving (Othman, 2014), political skill (Lu and Guy, 2018) and work ethics (Robles, 2012).

School of Built Environment, The University of New South Wales (UNSW), Sydney NSW 2052 AUSTRALIA

*Corresponding author: r.sunindijo@unsw.edu.au 
There is mounting evidence that El is regarded as an important interpersonal skill that differentiates individual performance in the workplace and influences organisational effectiveness (Goleman, 1998). Emotional intelligence is related to a variety of interpersonal outcomes, including the ability to understand the emotions of others, cooperative behaviour, positive interpersonal relationships, effective communication and teamwork (Schutte and Loi, 2014). Sunindijo (2012) stated that El is the foundation of interpersonal skill while Gong, Chen and Wang (2019) found that El has a positive predictive influence on job performance and is negatively correlated with burnout.

Despite the advancement of El research and the growth of the real estate sector in China, there is still limited research that focuses on El in this context. In addition, there is no research that investigates the El of overseas graduates. Filling this gap is crucial because the number of Chinese students studying overseas has increased exponentially and they are expected to have a significant influence on the development of China. Between 1978 and 2016, the number of Chinese students studying aboard increased from 860 to 544,500 (National Bureau of Statistics of China, 2017). This research, therefore, aims to assess the level of El of employees and its importance in the real estate sector in China. A comparison between Chinese overseas and local graduates in terms of their levels of El is also made.

\section{LITERATURE REVIEW}

The literature review is categorised into three sections. The first section discusses the importance of interpersonal skills and introduces the concept of El in the context of the real estate industry. The second section describes the phenomenon of overseas university graduates, particularly those from China. The third section combines the previous two sections to identify the research gap and develop hypotheses.

\section{Interpersonal Skills and EI}

Management literature has classified managerial skills into conceptual, interpersonal and technical skills. Technical skills are important for those at the lower management levels and become less important for those at the top. Conceptual skills, on the contrary, are more important for those higher up the management ladder than those in junior management positions. However, interpersonal skills are considered important in all management levels, particularly in today's dynamic and interconnected work environment. For instance, data collected from 768 managers and executives found that effective job performance relies on interpersonal skills, such as collaboration and communication (Bedwell, 2014). Other research found that an increase in a manager's political skill, which is considered as an interpersonal competence, is associated with an exponential increase in enterprise performance (Gansen-Ammann et al., 2019).

In the real estate industry, interpersonal skills have also been identified as an important skill in many countries. Othman (2014) found that trust and honesty, oral and written communication and problem solving are the three most important skills in South Africa. Human resource managers in Poon's (2012) study explained that interpersonal skills, such as professionalism, teamwork, report writing, communication, presentation skills and client care, are crucial in the real estate and construction 
industry in the UK. Sunindijo, Zou and Dainty (2017) found that interpersonal skills such as apparent sincerity and social awareness, are important for delivering positive safety outcomes in construction projects in Australia. Furthermore, Poon (2017) suggested that communication skills are crucial for graduates working in the real estate industry in Australia. There is even an expectation for graduates to possess the ability to speak a second language.

Research has shown that El affects a variety of interpersonal outcomes, including cooperative behaviour (Makkar and Basu, 2019), high quality social relationships (Leonidou et al., 2019), effective teamwork abilities (Su and Zhang, 2015) and better communication skills (Schutte and Loi, 2014). Sunindijo (2012) stated that El is a significant component and foundation of interpersonal skills in the construction industry. Individuals with high El can manage relationships and resolve conflicts effectively, an important quality in today's work environment where people are expected to be more and more interconnected (Sunindijo and Hadikusumo, 2014).

El is defined as the capacity for motivating ourselves, recognising our feelings and those of others and for managing emotions in our relationships as well as in ourselves (Goleman, 1998). It is a predictor of superior performance in various work roles (Miao, Humphrey and Qian, 2018) and research has found that emotionally intelligent people perform better than their counterparts (O'Boyle et al., 2011; Schutte and Loi, 2014).

El has four dimensions: (1) self-awareness, (2) self-management, (3) social awareness and (4) relationship management (Goleman, 2001). Self-awareness is the ability to identify one's own feelings and understand the causes of those feelings, which is the basis for assessing one's own abilities (Lee, 2018). Selfawareness is considered as a core skill in developing professional self and the ability to understand one's own experiences and feelings affects individuals' ability to understand and work with others (Blakemore and Agllias, 2019). Self-management allows individuals to regulate their emotions, while managing progress (Goleman, 1998). Individuals with high self-management capabilities are able to redirect emotions constructively, allowing them to manage pressures and stress and to think before acting, which is crucial to promoting positive relationships (Raghubir, 2018). Moreover, self-management enables individuals to hold in mind positive feelings, while inhibiting negative feelings (Sunindijo and Hadikusumo, 2014). Social awareness is associated with the awareness of others' demands, feelings and concerns, sympathising with others' emotions and understanding others' unspoken feelings (Goleman, 1998; Sharma and Singh, 2018). This ability is particularly essential to improve outcomes when interacting with others (Sunindijo and Hadikusumo, 2014). Lastly, relationship management is the culmination of the previous dimensions and is reflected by the ability to build and manage relationships with others through communicating effectively (Goleman, 1998) and inducing desirable responses in others (Sharma and Singh, 2018). Well-developed relationship management skills are essential for quality cooperation, collaboration and teamwork (Bradberry and Greaves, 2004; Raghubir, 2018).

\section{Chinese Overseas Graduates}

The number of international students has increased exponentially in the past two decades. For example, from 2012 to 2016, the number of international commencements in Australia increased by $45 \%$. In the same period, the share of 
commencing international students to all commencing students increased from $21.8 \%$ to $26.7 \%$. International education contributed more than USD30 billion to the Australian economy in 2017, making the sector the third largest export sector in the country (Birrell and Betts, 2018).

Among international students, Chinese students are one of the largest and fastest growing groups. They are the largest group of international students in eight major countries for education, including the United States (US), the United Kingdom (UK), Australia, Canada, Germany, Japan, Korea and New Zealand (Li and Qi, 2019). The rapid growth of international students in Australia, for example, can be attributed to Chinese students. For example, in a higher institution in Sydney, Chinese commencers made up $72 \%$ of all international commencing students (Birrell and Betts, 2018). Given China's economic growth, it is likely that this trend will be sustained.

Due to the large number of international students from China, research has been conducted to identify factors that motivate Chinese students to study overseas. Summarising from previous research, Li and Qi (2019) identified a range of factors, including gaining prestige, quality and variety of education, intrinsic personal attraction to a different culture, social and peer pressure, social and cultural experience and English-speaking environment.

Another important motivator is the perceived importance of international learning experience for future job searches and career development. Governments around the world encourage internationalising student learning experience to foster global knowledge and skills so that their human resources are able to respond to the demands of social, economic and labour market globalisation (Mok et al., 2017). Chinese students themselves often mention that an overseas degree from a top university is beneficial for their career choice and development (Li and Qi, 2019).

Despite the popularity of overseas education among Chinese students and its perceived benefit, the variables that influence Chinese overseas graduates when seeking jobs in China depend on a range of factors, including the reputation of the higher education institution (Bodycott, 2009), individuals' personality and the labour market contexts (Cai, 2014). The employment situation for Chinese overseas graduates is complex (Melik, 2012). Sometimes there is a negative attitude towards employing these graduates and it seems that their entry-level salaries are decreasing (Cai, 2014). Hao, Wen and Welch (2016) argued that overseas graduates are disadvantaged when accessing local networks as compared to local graduates. They are required to have an awareness of the domestic situation and to build trust with local stakeholders, which can be challenging due to their living overseas for a number of years (Buckley, Clegg and Tan, 2006). In addition, many Chinese overseas graduates usually have limited work experience and are perceived to be less mature because they have been fully dependent on their parents while studying overseas (Hao, Wen and Welch, 2016).

On the contrary, overseas graduates also have advantages because they are highly valued by international organisations (Huibo Research Institute, 2007) and some private and state-owned enterprises in China (SU and Zhang, 2015). Employers are looking for graduates from the top 500 universities in the world because they are perceived to produce high-quality graduates suitable in contemporary management environments to create economic advantage (Su and Zhang, 2015; Hao, Wen and Welch, 2016). Crossman and Clarke (2010) also suggested that international experience enhances employability because of 
the acquisition of second language and soft skills, such as cultural understanding and character development. Hao, Wen and Welch (2016) stated that overseas graduates learn to adapt quickly in a new environment and are able to solve new tasks more effectively than local graduates.

One survey revealed that the majority of employers prefer international study experience during talent recruitment because of a belief that graduates with international learning experience will outperform their local counterparts (Mok et al., 2017). Li et al. (2019) suggested that Chinese organisations can promote innovation by recruiting Chinese overseas graduates and experienced returnees who have international awareness and exposure. Mok et al. (2017) argued that interpersonal skills is one of the most important skills, according to employers, in the era of globalisation and they perceive that overseas graduates are better than local graduates in this quality.

\section{Formulation of Hypotheses}

Integrating the elements of $\mathrm{El}$ in the real estate sector and the popularity of overseas education among Chinese students, this research first assesses the level of El among practitioners in the real estate sector in China due to the limited research in this area. As discussed previously, El is considered as an important skill at work to facilitate positive interpersonal relationships with various stakeholders. Using communication skills and teamwork behaviour as proxies of interpersonal skills, this research seeks to establish the relationships between El and interpersonal skills in the context of the Chinese real estate sector. It is hypothesised that there are positive relationships between El and communication skills and teamwork behaviour. Furthermore, this research aims to establish differences between Chinese overseas graduates and local graduates in terms of their levels of El and interpersonal skills. Based on the perceived benefits of international learning, it is hypothesised that Chinese overseas graduates have higher El and interpersonal skills than their local counterparts.

\section{RESEARCH METHODS}

Both quantitative and qualitative methods were adopted in this research. In the quantitative method, a questionnaire was used to collect data. The questionnaire has 59 items, which was categorised into four sections. The first section contains 13 demographic questions. The second section is the Emotional Intelligence Appraisal (EIA) instrument developed by Bradberry and Greaves (2004), which consists of 28 items. The ElA was designed to assess the four dimensions of El, i.e., self-awareness, self-management, social awareness and relationship management and has been rigorously tested and validated across various industries and job positions. The remaining two sections measure the levels of communication skills and teamwork behaviour, which serve as proxies of interpersonal skills in this research. Twelve items were used to assess communication skills. The items were extracted from Robbins and Hunsaker (2008), who reviewed a large number of studies and synthesised the key components of communication skills. Teamwork behaviour was assessed by seven items, developed based on the dimensions in the knowledge, skills and abilities (KSA) model proposed by Stevens and Campion (1994). This model has been validated and widely used across various contexts. These two additional 
sections were used to demonstrate the influence of El on other key interpersonal skills. A 6-point Likert scale, i.e., "Never", "Rarely", "Sometimes", "Usually", "Almost always" and "Always" was used in sections two, three and four.

Pilot testing was conducted with two real estate employees in China. They were asked to ensure that the Chinese version of the instrument was clear and easy to understand and the length was appropriate. The pilot test revealed the instrument to be clear and appropriate. As suggested by the pilot study participants, the wordings in some items were revised to improve clarity. Furthermore, before commencing data collection, ethics approval was obtained from the institution's ethics committee.

Capitalising on the contacts that the researchers have in the real estate sector in China, the questionnaire was distributed to six state-owned real estate companies headquartered in Beijing, China, that agreed to participate. To ensure the reliability of the data, all the companies were chosen with similar characteristics, in that they are classified as Grade One (highest grade) real estate developers that have a range of major business activities, including quantity surveying, property development and facility management. It is also common for these companies to employ overseas graduates, which is an important criterion for this research. In total, 140 responses were collected from the six participating companies, representing a response rate of $65.34 \%$. SPSS Statistics version 25 (IBM, New York, USA) was used to conduct the quantitative analyses.

Besides using a questionnaire to collect quantitative data, face-to-face semi-structured interviews were conducted to collect qualitative data and enrich the interpretation of the results. The principles of triangulation underpinned the decision to collect the qualitative data. Triangulation is often used to describe research where at least two methods are used. In triangulation, results from different methods can complement each other and be used to supplement the individual results (Heale and Forbes, 2013). In the context of this research, triangulation was used to supplement and enrich the quantitative results using the qualitative results. Six human resource managers from the participating companies were invited to participate and four managers agreed to be interviewed. Since the research aims to determine the importance of $\mathrm{El}$ in the real estate sector and compare the $\mathrm{El}$ of local and overseas graduates, interviewing human resource managers can capture the valuable perspectives of the employers. The interviews focused on the importance of $\mathrm{El}$ in this sector according to the employers and the reasoning behind and the expectations of, employing local and overseas graduates. Specifically, the following questions were asked during the interviews:

1. What kind of candidates are you looking for? Do you prefer local graduates or overseas graduates?

2. Are there different expectations for local and overseas graduates?

3. What are the interpersonal skills sought from new recruits in your company?

4. Do you consider the emotional intelligence of applicants during the recruitment process?

5. Is proficiency in English important in recruitment?

6. Do you have any suggestions for overseas graduates who are seeking employment in the Chinese real estate sector? 
The interview data were analysed using the principles of thematic analysis. Thematic analysis is a method for identifying, analysing and reporting patterns or themes within data. A theme, which is a pattern found in the data, can range from simply describing and organising possible observations to interpreting aspects of the phenomenon. A theme can be explicit, directly observable in the data, or can be implicit, representing an aspect that underlies the phenomenon (Boyatzis, 1998). The stages proposed by Braun and Victoria (2006) were used to conduct the thematic analysis:

1. Data familiarisation, which involves transcribing, rereading interview data and jotting down notes and ideas inductively.

2. Generating initial codes and matching them with the data extracts.

3. Sorting the codes into potential themes. In this research, theme development was governed by the two research objectives, which is to understand the importance of $\mathrm{El}$ in the real estate sector and to understand the rationale of employing local and overseas graduates.

4. Reviewing themes and subthemes to ensure their coherence and distinction.

5. Defining the themes and subthemes by determining their essence and the aspects of the data that they capture.

6. Reporting by not only describing the data but putting forward arguments related to the research objectives.

\section{ANALYSIS AND DISCUSSION}

Table 1 presents the characteristics of the respondents and $17 \%$ of the respondents had overseas education.

Table 1. Profile of Respondents

\begin{tabular}{llcc}
\hline Demographic Variables & & Frequency & $\%$ \\
\hline Gender & Female & 52 & 37 \\
& Male & 87 & 62 \\
& Unknown & 1 & 1 \\
Age & 18 to 24 years old & 13 & 9 \\
& 25 to 29 years old & 51 & 36 \\
& 30 to 34 years old & 50 & 36 \\
& 35 to 39 years old & 16 & 11 \\
& 40 to 44 years old & 5 & 4 \\
& 45 to 49 years old & 2 & 1 \\
& 50 to 60 years old & 1 & 1 \\
Unknown & 2 & 1 \\
\hline
\end{tabular}


Table 1. Continued

\begin{tabular}{|c|c|c|c|}
\hline Demographic Variables & & Frequency & $\%$ \\
\hline \multirow[t]{6}{*}{ Highest level of education } & Diploma & 15 & 11 \\
\hline & Bachelor & 64 & 46 \\
\hline & Master & 53 & 38 \\
\hline & Doctorate (PhD) & 3 & 2 \\
\hline & High school & - & - \\
\hline & Unknown & 5 & 4 \\
\hline \multirow[t]{3}{*}{ Overseas study experience } & No & 104 & 74 \\
\hline & Yes & 24 & 17 \\
\hline & Unknown & 12 & 9 \\
\hline \multirow[t]{3}{*}{ Graduation year } & Less than 10 years & 106 & 76 \\
\hline & Greater than 10 years & 22 & 16 \\
\hline & Unknown & 12 & 9 \\
\hline \multirow[t]{6}{*}{ How easy to find a job } & Extremely difficult & 5 & 4 \\
\hline & Moderately difficult & 8 & 6 \\
\hline & Slightly difficult & 60 & 43 \\
\hline & Slightly easy & 54 & 39 \\
\hline & Moderately easy & 7 & 5 \\
\hline & Extremely easy & 6 & 4 \\
\hline \multirow[t]{6}{*}{ Satisfaction } & Extremely dissatisfied & - & - \\
\hline & Moderately dissatisfied & - & - \\
\hline & Slightly dissatisfied & 18 & 13 \\
\hline & Slightly satisfied & 88 & 63 \\
\hline & Moderately satisfied & 22 & 16 \\
\hline & Extremely satisfied & 12 & 9 \\
\hline \multirow[t]{6}{*}{ Learning experience } & Strongly disagree & 1 & 1 \\
\hline & Disagree & 2 & 1 \\
\hline & Somewhat disagree & 19 & 14 \\
\hline & Somewhat agree & 75 & 54 \\
\hline & Agree & 28 & 20 \\
\hline & Strongly agree & 15 & 11 \\
\hline
\end{tabular}

(Continued on next page) 
Table 1. Continued

\begin{tabular}{llcr}
\hline Demographic Variables & & Frequency & $\%$ \\
\hline English skill & Non-user & 12 & 9 \\
& Limited & 36 & 26 \\
& Modest & 40 & 29 \\
& Competent & 11 & 8 \\
& Good & 26 & 19 \\
& Very good & 10 & 7 \\
& Expert & 5 & 4 \\
\hline
\end{tabular}

Note: Unknown = The respondent did not respond to the question.

\section{Emotional Intelligence in the Real Estate Sector in China}

Table 2 shows the levels of El, communication skills and teamwork behaviour of the respondents. The level of El was calculated based on the guidelines of the EIA instrument. The overall El scores of the respondents range from 52 to 95 with an average score of 76.86. The average El score of tens of thousands of respondents across industries and professions as revealed in the guidebook is 75. One sample $t$-test was used to compare the average score of this research with the score in the guidebook and found no significance difference. This is an indicator that the result reflects the general population and is valid.

Table 2. Levels of El, Communication Skills and Teamwork Behaviours

\begin{tabular}{llrrrrrr}
\hline Code & Description & N & Minimum & Maximum & Mean & Rank & $\begin{array}{c}\text { Std. } \\
\text { Deviation }\end{array}$ \\
\hline E1 & Self-awareness & 140 & 61 & 98 & 79.95 & 1 & 7.298 \\
E2 & Self-management & 140 & 37 & 98 & 75.99 & 3 & 11.551 \\
E3 & Social awareness & 140 & 54 & 100 & 78.41 & 2 & 8.567 \\
E4 & Relationship & 140 & 36 & 96 & 72.81 & 4 & 12.485 \\
& management & & & & & & \\
E5 & Overall El score & 140 & 52 & 95 & 76.86 & - & 8.092 \\
\hline C1 & Congruent with my & 140 & 3 & 6 & 4.61 & 1 & 0.862 \\
& message & & & & & & \\
C2 & Send message clearly & 140 & 2 & 6 & 4.47 & 4 & 0.809 \\
C3 & Eye contact & 140 & 2 & 6 & 4.55 & 3 & 0.892 \\
C4 & Factual content & 140 & 2 & 6 & 4.41 & 5 & 0.856 \\
C5 & Presentation & 140 & 1 & 6 & 3.69 & 11 & 1.080 \\
C6 & Withhold judgement & 140 & 1 & 6 & 4.28 & 9 & 1.053 \\
C7 & Do not interrupt & 140 & 2 & 6 & 4.39 & 6 & 0.919 \\
\hline
\end{tabular}


Table 2. Continued

\begin{tabular}{|c|c|c|c|c|c|c|c|}
\hline Code & Description & $N$ & Minimum & Maximum & Mean & Rank & $\begin{array}{c}\text { Std. } \\
\text { Deviation }\end{array}$ \\
\hline C8 & Ask question & 140 & 2 & 6 & 4.30 & 8 & 0.879 \\
\hline C9 & Tailor the feedback & 140 & 2 & 6 & 4.20 & 10 & 0.883 \\
\hline $\mathrm{C} 10$ & $\begin{array}{l}\text { Give objective } \\
\text { comments }\end{array}$ & 140 & 1 & 6 & 4.36 & 7 & 0.915 \\
\hline $\mathrm{C} 11$ & $\begin{array}{l}\text { Communication with } \\
\text { people from different } \\
\text { cultures }\end{array}$ & 140 & 2 & 6 & 4.41 & 5 & 1.045 \\
\hline $\mathrm{C} 12$ & $\begin{array}{l}\text { Communication } \\
\text { method }\end{array}$ & 140 & 2 & 6 & 4.59 & 2 & 0.921 \\
\hline $\mathrm{Tl}$ & Manage conflicts & 140 & 2 & 6 & 4.32 & 6 & 0.908 \\
\hline $\mathrm{T} 2$ & Clarify individual task & 140 & 1 & 6 & 4.54 & 2 & 0.917 \\
\hline T3 & Clarify collective task & 140 & 2 & 6 & 4.64 & 1 & 0.946 \\
\hline $\mathrm{T} 4$ & $\begin{array}{l}\text { Provide creative } \\
\text { ideas to solve } \\
\text { problems }\end{array}$ & 140 & 2 & 6 & 4.34 & 5 & 0.935 \\
\hline T5 & $\begin{array}{l}\text { Seek the root of } \\
\text { problem }\end{array}$ & 140 & 2 & 6 & 4.42 & 4 & 1.025 \\
\hline T6 & $\begin{array}{l}\text { Encourage people } \\
\text { toward same goal }\end{array}$ & 140 & 2 & 6 & 4.46 & 3 & 0.925 \\
\hline T7 & $\begin{array}{l}\text { Give feedback to } \\
\text { others }\end{array}$ & 140 & 1 & 6 & 4.32 & 6 & 1.006 \\
\hline
\end{tabular}

Note: Mean; 1 = Never; 2 = Rarely; 3 = Sometimes; 4 = Usually; $5=$ Almost Always; 6 = Always.

Cronbach's alpha was used to test the reliability of the communication skills and teamwork behaviour sections of the questionnaire because they were adapted from existing questionnaires. The Cronbach's alpha values are 0.876 and 0.907, respectively, much higher than the 0.7 cut-off value, which indicates that the instruments are reliable. The most frequently used communication skills were congruent messaging $(M=4.61)$, being flexible in using various communication methods (e.g., face-to-face, email or phone) $(M=4.59)$ and maintaining eye contact $(M=4.55)$. In contrast, giving a presentation $(M=3.69)$ was the skill used least frequently by the respondents. In terms of teamwork behaviours, the most frequent behaviour demonstrated by the respondents were clarifying collective tasks $(M=4.64)$ and individual tasks $(M=4.54)$. On the other hand, giving feedback $(M=4.32)$ and managing conflicts $(M=4.32)$ were the least frequent behaviours demonstrated by the respondents. It must be noted that the difference between the most frequent and least frequently used teamwork behaviour is marginal, indicating that the respondents demonstrated all behaviours relatively equally in their work.

Table 3 presents the results of the Pearson's correlation analysis between El and communication skills and teamwork behaviour. There are significant correlations (at 0.01 level) between the overall El score and communication skills and teamwork 
behaviour. Similarly, there are significant correlations between dimensions of El and communication skills and teamwork behaviour. This means that the higher the El score, the more frequent the respondents exhibited a range of communication skills and teamwork behaviour. This confirms the first hypothesis, which demonstrates the influence of El on other interpersonal skills in the real estate sector in China and confirms the role of El as the foundation of interpersonal skills as asserted in previous studies (for example, Sunindijo, 2012). The noteworthy correlations also serve to confirm the criterion validity of the instruments to measure communication skills and teamwork behaviour.

Table 3. Correlations between Communication Skills and Dimensions of El

\begin{tabular}{|c|c|c|c|c|c|}
\hline $\begin{array}{l}\text { Communication } \\
\text { Skills and Teamwork } \\
\text { Behaviour }\end{array}$ & $\begin{array}{l}\text { Self- } \\
\text { Awareness }\end{array}$ & $\begin{array}{c}\text { Self- } \\
\text { Management }\end{array}$ & $\begin{array}{c}\text { Social } \\
\text { Awareness }\end{array}$ & $\begin{array}{l}\text { Relationship } \\
\text { Management }\end{array}$ & $\begin{array}{l}\text { Overall } \\
\text { El Score }\end{array}$ \\
\hline $\begin{array}{l}\mathrm{Cl} \text { Congruent with } \\
\text { my message }\end{array}$ & $0.336^{* *}$ & $0.552^{* *}$ & $0.436^{* *}$ & $0.617^{* *}$ & $0.634^{* *}$ \\
\hline $\begin{array}{l}\text { C2 Send message } \\
\text { clearly }\end{array}$ & $0.299^{* *}$ & $0.454^{* *}$ & $0.447^{* *}$ & $0.633^{* *}$ & $0.599^{* *}$ \\
\hline C3 Eye contact & $0.273^{* *}$ & $0.456^{* *}$ & $0.428^{* *}$ & $0.548^{* *}$ & $0.555^{* *}$ \\
\hline C4 Factual content & $0.442^{* *}$ & $0.452^{* *}$ & $0.539^{* *}$ & $0.540^{* *}$ & $0.620^{* *}$ \\
\hline C5 Presentation & 0.175 & 0.158 & $0.277^{* *}$ & $0.553^{* *}$ & $0.385^{* *}$ \\
\hline $\begin{array}{l}\text { C6 Withhold } \\
\text { judgement }\end{array}$ & $0.346^{* *}$ & $0.395^{* *}$ & $0.359^{* *}$ & $0.431^{* *}$ & $0.488^{* *}$ \\
\hline C7 Do not interrupt & $0.396^{* *}$ & $0.519^{* *}$ & $0.454^{* *}$ & $0.528^{* *}$ & $0.607^{* *}$ \\
\hline C8 Ask question & $0.422^{* *}$ & $0.335^{* *}$ & $0.392^{* *}$ & $0.475^{* *}$ & $0.511^{* *}$ \\
\hline $\begin{array}{l}\text { C9 Tailor the } \\
\text { feedback }\end{array}$ & $0.483^{* *}$ & $0.405^{* *}$ & $0.423^{* *}$ & $0.599^{* *}$ & $0.604^{* *}$ \\
\hline $\begin{array}{l}\text { C10 Give objective } \\
\text { comments }\end{array}$ & $0.494^{* *}$ & $0.462^{* *}$ & $0.432^{* *}$ & $0.521^{* *}$ & $0.597^{* *}$ \\
\hline $\begin{array}{l}\text { C11 Different } \\
\text { cultures }\end{array}$ & $0.387^{* *}$ & $0.420^{* *}$ & $0.434^{* *}$ & $0.432^{* *}$ & $0.521^{* *}$ \\
\hline $\begin{array}{l}\text { C12 Communication } \\
\text { method (e.g., phone) }\end{array}$ & $0.246^{* *}$ & $0.522^{* *}$ & $0.415^{* *}$ & $0.472^{* *}$ & $0.534^{* *}$ \\
\hline $\begin{array}{l}\text { T1 Manage } \\
\text { conflicts }\end{array}$ & $0.406^{* *}$ & $0.559^{* *}$ & $0.520^{* *}$ & $0.568^{* *}$ & $0.657^{* *}$ \\
\hline $\begin{array}{l}\text { T2 Clarify individual } \\
\text { task }\end{array}$ & $0.426^{* *}$ & $0.551^{* *}$ & $0.550^{* *}$ & $0.481^{* *}$ & $0.630^{* *}$ \\
\hline $\begin{array}{l}\text { T3 Clarify collective } \\
\text { task }\end{array}$ & $0.382^{* *}$ & $0.574^{* *}$ & $0.575^{* *}$ & $0.527^{* *}$ & $0.654^{* *}$ \\
\hline $\begin{array}{l}\text { T4 Provide creative } \\
\text { ideas to solve } \\
\text { problems }\end{array}$ & $0.420^{* *}$ & $0.504^{* *}$ & $0.494^{* *}$ & $0.672^{* *}$ & $0.673^{* *}$ \\
\hline
\end{tabular}


Table 3. Continued

\begin{tabular}{lccccc}
\hline $\begin{array}{l}\text { Communication } \\
\text { Skills and Teamwork } \\
\text { Behaviour }\end{array}$ & $\begin{array}{c}\text { Self- } \\
\text { Awareness }\end{array}$ & $\begin{array}{c}\text { Self- } \\
\text { Management }\end{array}$ & $\begin{array}{c}\text { Social } \\
\text { Awareness }\end{array}$ & $\begin{array}{c}\text { Relationship } \\
\text { Management }\end{array}$ & $\begin{array}{c}\text { Overall } \\
\text { El Score }\end{array}$ \\
\hline $\begin{array}{l}\text { T5 Seek the root of } \\
\text { problem }\end{array}$ & $0.463^{* *}$ & $0.521^{* *}$ & $0.489^{* *}$ & $0.542^{* *}$ & $0.637^{* *}$ \\
$\begin{array}{l}\text { T6 Encourage } \\
\text { people toward the } \\
\text { same goal }\end{array}$ & $0.407^{* *}$ & $0.542^{* *}$ & $0.552^{* *}$ & $0.657^{* *}$ & $0.695^{* *}$ \\
$\begin{array}{l}\text { T7 Give feedback } \\
\text { to others }\end{array}$ & $0.262^{* *}$ & $0.391^{* *}$ & $0.307^{* *}$ & $0.556^{* *}$ & $0.501^{* *}$ \\
\hline
\end{tabular}

Note: ${ }^{* *} 0.0 .01$ level of significance (2-tailed).

When asked about El and interpersonal skills, the human resource managers strongly acknowledged their importance in the real estate industry as noted in the following quotations: "El is very important because all jobs in the real estate industry involve dealing with people", "El is extremely important, particularly when communicating with others to solve problems towards a common goal. The higher the position, the higher the El requirement" and "El and interpersonal skills are definitely important. They are needed to understand the social value system in China and to operate effectively within that system".

Managing various stakeholders, such as government officials, designers, contractors and clients, is critical when working in the real estate industry. In this case, El is needed to understand social contexts and adapt behaviour according to those contexts to achieve desirable outcomes (Sharma and Singh, 2018). Furthermore, the real estate industry is known for its conflict-laden environment (Maiti and Choi, 2018) and El is important for negotiation and achieving compromise which maximises the interests of each party (Leonidou et al., 2019).

In addition, a human resource manager appreciates El in the recruitment process because people with high El can control their emotions and adapt to the new work environment by embracing the values and culture in the organisation. They can quickly adapt their behaviour when dealing with their superiors and also can manage their subordinates effectively. After successfully integrating themselves into the organisation's culture, they can then contribute more by asserting their own values and ideas that will bring positive change to further advance the organisation. This aligns with previous research which found that emotional intelligence enables individuals to adapt to environmental changes and to resolve conflict effectively when dealing with others (Darvishmotevali, Altinay and De Vita, 2018).

To summarise, El is indeed an important skill for those working in the real estate industry because the industry demands its practitioners to interact with and manage the expectations of, various stakeholders who have differing agendas. Those with high El are able to manage their emotions and understand the social contexts in which they operate. Capitalising on this understanding, they are able to adapt their behaviour to match the cultural and social values of those contexts. This adaptive ability allows them to effectively communicate and build relationships with others and negotiate to achieve common goals. 


\section{Comparison between Chinese Overseas and Local Graduates}

Table 4 presents the result of the two-sample t-test, which shows the differences between overseas and local graduates regarding various factors in this research. There are four significant differences with $p$-values less than 0.05 . First, the results indicate that it is easier for local graduates to find jobs in the real estate sector in China (3.59 vs 3.17; $p$-value $=0.050$ ). This is in contrast to the literature that suggests that employers prefer overseas graduates due to their international awareness and exposure (Mok et al., 2017). Likewise, the perceived benefit of international education in career choice and development is not supported by this finding. The finding is further supported by the interviews with the human resource managers, who explained that "Overseas graduates are preferred in the design department because they have a broader view. However, we prefer to hire local graduates for the finance department or human resource department, since they have better understanding of Chinese business culture" and "We prefer to hire graduates from local elite universities, such as Beijing University and Tsinghua University, because they have good networks with their alumni. Their networks will benefit our company".

These statements suggest that local graduates are preferred by real estate companies in China, particularly because of their understanding of Chinese business culture and their alumni networks. One human resource manager also explicitly added that Chinese elite universities are better than many of the top 100 universities in the world. Yang and Welch (2012) also found that graduates from elite Chinese universities are more popular than overseas graduates due to their teaching quality and alignment with China's economic and social development needs.

Table 4. Differences between Chinese Overseas and Local Graduates

\begin{tabular}{|c|c|c|c|c|c|c|}
\hline \multirow{2}{*}{ Code } & \multirow{2}{*}{ Description } & \multicolumn{2}{|c|}{ Local } & \multicolumn{2}{|c|}{ Overseas } & \multirow[b]{2}{*}{ Sig. 2-tailed } \\
\hline & & Mean & $N$ & Mean & $N$ & \\
\hline G7 & How easy to find a job & 3.59 & 104 & 3.17 & 24 & $0.050^{*}$ \\
\hline G8 & Job satisfaction & 4.21 & 104 & 4.29 & 24 & 0.641 \\
\hline G9 & $\begin{array}{l}\text { Learning experience is } \\
\text { valuable for work }\end{array}$ & 4.24 & 104 & 4.38 & 24 & 0.523 \\
\hline G10 & English skill & 3.04 & 104 & 4.92 & 24 & $0.000^{* *}$ \\
\hline El & Self-awareness & 79.72 & 104 & 80.79 & 24 & 0.449 \\
\hline E2 & Self-management & 76.54 & 104 & 75.54 & 24 & 0.691 \\
\hline E3 & Social awareness & 78.16 & 104 & 78.17 & 24 & 0.999 \\
\hline E4 & Relationship management & 72.48 & 104 & 74.38 & 24 & 0.494 \\
\hline E5 & Overall El score & 76.80 & 104 & 77.29 & 24 & 0.784 \\
\hline $\mathrm{Cl}$ & Congruent with my message & 4.65 & 104 & 4.63 & 24 & 0.857 \\
\hline C2 & Send message clearly & 4.48 & 104 & 4.42 & 24 & 0.729 \\
\hline C3 & Eye contact & 4.57 & 104 & 4.58 & 24 & 0.935 \\
\hline
\end{tabular}


Table 4. Continued

\begin{tabular}{|c|c|c|c|c|c|c|}
\hline \multirow{2}{*}{ Code } & \multirow{2}{*}{ Description } & \multicolumn{2}{|c|}{ Local } & \multicolumn{2}{|c|}{ Overseas } & \multirow[b]{2}{*}{ Sig. 2-tailed } \\
\hline & & Mean & $N$ & Mean & $N$ & \\
\hline $\mathrm{C} 4$ & Factual content & 4.41 & 104 & 4.42 & 24 & 0.987 \\
\hline C5 & Presentation & 3.57 & 104 & 4.08 & 24 & $0.035^{*}$ \\
\hline C6 & Withhold judgement & 4.32 & 104 & 4.21 & 24 & 0.594 \\
\hline C7 & Don't interrupt & 4.39 & 104 & 4.29 & 24 & 0.656 \\
\hline $\mathrm{C} 8$ & Ask question & 4.30 & 104 & 4.33 & 24 & 0.864 \\
\hline C9 & Tailor the feedback & 4.17 & 104 & 4.33 & 24 & 0.420 \\
\hline $\mathrm{C} 10$ & Give objective comments & 4.41 & 104 & 4.13 & 24 & 0.155 \\
\hline C11 & $\begin{array}{l}\text { Communicate with people } \\
\text { from different cultures }\end{array}$ & 4.39 & 104 & 4.50 & 24 & 0.657 \\
\hline $\mathrm{C} 12$ & Communication method & 4.59 & 104 & 4.42 & 24 & 0.413 \\
\hline $\mathrm{T} 1$ & Manage conflicts & 4.38 & 104 & 4.21 & 24 & 0.385 \\
\hline T2 & Clarify individual task & 4.63 & 104 & 4.25 & 24 & 0.062 \\
\hline T3 & Clarify collective task & 4.76 & 104 & 4.29 & 24 & $0.027^{*}$ \\
\hline T4 & $\begin{array}{l}\text { Provide creative ideas to solve } \\
\text { problems }\end{array}$ & 4.34 & 104 & 4.42 & 24 & 0.699 \\
\hline T5 & Seek the root of problem & 4.53 & 104 & 4.21 & 24 & 0.159 \\
\hline T6 & $\begin{array}{l}\text { Encourage people toward } \\
\text { same goal }\end{array}$ & 4.56 & 104 & 4.21 & 24 & 0.085 \\
\hline T7 & Give feedback to others & 4.37 & 104 & 4.25 & 24 & 0.600 \\
\hline
\end{tabular}

Note: * Significantly different at 0.05 level (2-tailed); ** Significantly different at 0.01 level (2-tailed).

Second, it is understandable that overseas graduates have better English skills than local graduates (3.04 vs 4.92; p-value $=0.000$ ). However, English proficiency may not be an essential skill in Chinese real estate companies. The interviewees mentioned that they do not expect their employees to use English, although some proficiency in English may be needed when involved in international projects. For example, one interviewee stated that "All the suppliers are from China, so there is no English requirement in the recruitment process".

Third, there is an indication that overseas graduates are more comfortable in giving presentations or public speaking than local graduates (3.57 vs 4.08; $p$-value $=0.035$ ). This finding suggests that overseas graduates have higher selfconfidence due to their international learning experience (Hao, Wen and Welch, 2016). Nowadays there is a need for employees to give oral presentations and perform well in public speaking. In this case, overseas graduates have more opportunities to improve their self-confidence and presentation skills during their study, which can become their competitive advantage.

Fourth, local graduates tend to clarify collective tasks more frequently than overseas graduates (4.76 vs 4.29; $p$-value $=0.027$ ). This finding may be explained by the interview results, which suggest that overseas graduates are influenced 
by Western-style education, making them more independent and experiencing difficulty in adapting to Chinese business culture. Li and Feng (2018) found that international learning experience may reduce Chinese students' evaluation of China's overall situation and future prospects. Furthermore, two interviewees said "For us, who have been working in this company for many years, we all know if the leader asks you to do something, you just follow his instructions, but many young overseas graduates always have their own ideas" and "Most local graduates have a set mind. We admire young people who think out of the box, but many stateowned companies don't".

Fifth, as presented in Table 4, it is important to note that there is no difference in the levels of El and interpersonal skills between overseas and local graduates, thus the second hypothesis is rejected. This may mean that there are factors other than higher education that affect El development in the real estate sector. This is a worthy endeavour for future research.

In addition, the interviewees were asked about the skills that need to be improved among current graduates. They responded that both overseas and local graduates lack time management skills, stress management ability and motivation. These graduates were expected to learn quickly, be hard working, adapt to the company culture and be professional. Overseas graduates usually receive better pay and were expected to have a wiser and broader view that could be translated into better performance. Hao and Welch (2012) argued that overseas graduates needed to obtain an in-depth understanding of the Chinese business environment and without this understanding, they would face re-integration issues. For local graduates, local alumni networks and past work experience in other local companies are considered to be valuable assets.

Interviewees also gave several cautionary hints for overseas graduates seeking to enter into the real estate industry in China:

1. Adapting to China's business culture is very important.

2. You should have a career plan before going aboard and relevant internship experience is a big problem if you want to return to China.

3. You not only have to look up at the stars but also have to be down to earth.

As explained by Ai and Wang (2017), cultural shock is a challenge faced by Chinese overseas returnees. It is important for them to quickly adapt and operate within the existing business culture in China. Successful integration to local culture can then open the way to slowly change local practices for building competitive advantage and contributing to the betterment of society.

In summary, these results show that there is no difference in the levels of El between Chinese local and overseas graduates, indicating that there are other factors besides higher education that affect El development in this context. Being independent, able to think creatively and to be confident in public speaking are qualities that differentiate overseas graduates from their local counterparts. However, they need to apply these qualities within the constraints of Chinese business culture. Understanding social contexts and managing relationships within these contexts is the key for success. It shows again that interpersonal skills, particularly El, are important for overseas graduates and will help them adapt to and develop their careers in, the real estate industry in China. It is important to note that El has been proven to facilitate successful work performance across cultures. 


\section{CONCLUSION}

This research found that the level of El of real estate employees in China is average, which is approximately the same as the level in the population generally, for which data were collected across professions and industries globally. Supporting the finding drawn from previous research, this research found that El is an important quality in the Chinese real estate industry because it influences other key interpersonal skills, such as communication skills and teamwork behaviour. El is particularly important because dealing with various stakeholders and managing their expectations are major tasks for those working in this industry.

It is interesting to note that overseas education does not seem to have any impacts on the level of El because the survey suggests the El of overseas graduates is no different from the El of local graduates. As such, there may be other factors that influence the development of El in the real estate sector in China, a topic that can be investigated in future research.

The research also found that overseas graduates seem to be better in giving presentations or in public speaking and in thinking innovatively than local graduates. They are also better in communicating in English, which is understandable due to their educational training. However, local graduates are better in clarifying collective tasks, which is probably due to their deeper understanding of local Chinese culture and their collectivistic norms. There is also a perception that it is more difficult for overseas graduates to find jobs because Chinese real estate companies prefer to employ local graduates from elite Chinese universities who have strong local networks and a deep understanding of local culture. It is important, therefore, for overseas graduates to understand the social context in China and adapt quickly to local cultures, while applying the positive qualities of their international learning within those contexts. High El is a way to accomplish this because El has been found to promote success across all cultures.

There are several research limitations that must be mentioned. First, quantitative data were collected from six Grade One real estate companies in China. As such, the results may not represent the entire population of the real estate sector and may not be generalisable to other contexts. However, the companies were chosen carefully to ensure that their characteristics were sufficiently similar to ensure the reliability of the results within that context. Future research could collect data from more companies in China to validate the findings. Second, qualitative data were collected from four human resource managers with the purpose of gaining insights from the perspective of the employers on the matters being investigated. More data could be collected to validate the findings. Interviews can also be conducted with top managers as opposed to human resource managers to understand the rationale in recruiting local and overseas graduates into real estate companies in China. Third, common method biases due to the use of survey and semi-structured interviews may occur although an appropriate research process has been followed to minimise its occurrence. Fourth, communication skills and teamwork behaviour were used as proxies of interpersonal skills, so they do not represent interpersonal skills comprehensively. There may also be other elements that can be used to better assess communication skills and teamwork behaviour. However, this research used instruments and items that have been previously validated to address this limitation. This research also found that the instruments are reliable and valid. 
Besides expanding the research into other contexts, there are several specific recommendations for future research. First, the characteristics of the respondents may influence the results and should be investigated further. For example, the length of stay overseas and the field of study may influence the levels of El and interpersonal skills. Second, this research found that there is no difference in the level of El between local and overseas graduates. Finding factors that affect the El of graduates in the real estate sector in China is a worthy endeavour due to the growth of the industry and the influence of El on job performance. Third, collecting qualitative data from overseas and local graduates is valuable and would provide deeper understanding of the skills required and employer expectations in the real estate sector in China. Fourth, this research can be extended to other industries, such as finance, manufacturing, education and information technology, that are considered the largest employers of overseas graduates in China.

\section{REFERENCES}

Ai, B. and Wang, L. (2017). Homeland integration: An academic returnee's experiences in Chinese universities. International Journal of Qualitative Methods, 16(1): 1-9. https://doi.org/10.1177/1609406917696741.

Bedwell, L.W. (2014). Developing the future workforce: An approach for integrating interpersonal skills into the MBA classroom. Academy of Management Learning and Education, 13(2): 171-186. https://doi.org/10.5465/amle.2011.0138.

Birrell, B. and Betts, K. (2018). Australia's Higher Education Overseas Student Industry: In a Precarious State. Middle Camberwell, Australia: The Australian Population Research Institute.

Blakemore, T. and Agllias, K. (2019). Student reflections on vulnerability and selfawareness in a social work skills course. Australian Social Work, 72(1): 21-33. https://doi.org/10.1080/0312407X.2018.1516793.

Bodycott, P. (2009). Choosing a higher education study abroad destination: What mainland Chinese parents and students rate as important. Journal of Research in International Education, 8(3): 349-373. https://doi.org/10 $.1177 / 1475240909345818$.

Boyatzis, R.E. (1998). Transforming Qualitative Information: Thematic Analysis and Code Development. Thousand Oaks, CA: SAGE Publications.

Bradberry, T. and Greaves, J. (2004). The Emotional Intelligence Appraisal: Me Edition; There is More Than IQ. San Diego: TalentSmart.

Braun, V. and Victoria, C. (2006). Using thematic analysis in psychology. Qualitative Research in Psychology, 3(2): 77-101. https://doi.org/10.1191/ 1478088706qp063oa.

Buckley, P.J., Clegg, J. and Tan, H. (2006). Cultural awareness in knowledge transfer to China: The role of Guanxi and Mianzi. Journal of World Business, 41 (3): 275-288. https://doi.org/10.1016/j.jwb.2006.01.008.

Cai, Y. (2014). Enhancing overseas Chinese graduate employability: The case of Chinese graduates with Finnish academic qualifications. Frontiers of Education in China, 9(3): 377-402. https://doi.org/10.1007/BF03397028.

Crossman, J.E. and Clarke, M. (2010). International experience and graduate employability: Stakeholder perceptions on the connection. Higher Education, 59(5): 599-613. https://doi.org/10.1007/s10734-009-9268-z. 
Darvishmotevali, M., Altinay, L. and De Vita, G. (2018). Emotional intelligence and creative performance: Looking through the lens of environmental uncertainty and cultural intelligence. International Journal of Hospitality Management, 73: 44-54. https://doi.org/10.1016/j.ijhm.2018.01.014.

Gansen-Ammann, D.-N., Meurs, J.A., Wihler, A. and Blickle, G. (2019). Political skill and manager performance: Exponential and asymptotic relationships due to differing levels of enterprising job demands. Group and Organization Management, 44(4): 718-744. https://doi.org/10.1177/1059601117747487.

Goleman, D. (2001). An El-based theory of performance. In C. Cherniss and D. Goleman (eds.), The Emotionally Intelligent Workplace: How to Select for, Measure and Improve Emotional Intelligence in Individuals, Groups and Organizations. San Francisco: Jossey-Bass, 27-44. . (1998). Working with Emotional Intelligence. New York: Bantam.

Gong, Z., Chen, Y. and Wang, Y. (2019). The influence of emotional intelligence on job burnout and job performance: Mediating effect of psychological capital. Frontiers in Psychology, 10: Article 2707. https://doi.org/10.3389/ fpsyg.2019.02707.

Hao, J. and Welch, A. (2012). A tale of sea turtles: Job-seeking experiences of hai gui (high-skilled returnees) in China. Higher Education Policy, 25(2): 243-260. https://doi.org/10.1057/hep.2012.4.

Hao, J., Wen, W. and Welch, A. (2016). When sojourners return: Employment opportunities and challenges facing high-skilled Chinese returnees. Asian and Pacific Migration Journal, 25(1): 22-40. https://doi.org/10.1177/ 0117196815621806.

Heale, R. and Forbes, D. (2013). Understanding triangulation in research. Evidence Based Nursing, 16(4): 98. https://doi.org/10.1136/eb-2013-101494.

Huibo Research Institute (2007). 海归人才现状分析报告 [Research report on the employment situation of Chinese returnees]. 慧博研究 [Huibo Research], 3(1): 21-33.

Lee, H.J. (2018). How emotional intelligence relates to job satisfaction and burnout in public service jobs. International Review of Administrative Sciences, 84(4): 729-745. https://doi.org/10.1177/0020852316670489.

Leonidou, L.C., Akyol, B., Fotiadis, T.A., Zeriti, A. and Christodoulides, P. (2019). The role of exporters' emotional intelligence in building foreign customer relationship. Journal of International Marketing, 27(4): 58-80. https://doi .org/10.1177/1069031X19876642.

Li, Z. and Feng, S. (2018). Overseas study experience and students' attitudes toward China: Evidence from the Beijing college students panel survey. Chinese Sociological Review, 50(1): 27-52. https://doi.org/10.1080/21620555.2017.134 4548.

Li, F. and Qi, H. (2019). An investigation of push and pull motivations of Chinese tourism doctoral students studying overseas. Journal of Hospitality, Leisure, Sport and Tourism Education, 24: 90-99. https://doi.org/10.1016/J.JHLSTE .2019 .01 .002 .

Li, L.Q., Xin, K., Pucik, V. and Wei, W.X. (2019). MNCs' R\&D talent management in China: Aligning practices with strategies. Chinese Management Studies, 13(4): 1086-1106. https://doi.org/10.1108/CMS-10-2018-0703.

Lu, X. and Guy, M.E. (2018). Political skill, organizational justice and career success in mainland China. International Review of Administrative Sciences, 84(2): 371-388. https://doi.org/10.1177/0020852315619025. 
Maiti, S. and Choi, J. (2018). Investigation and implementation of conflict management strategies to minimize conflicts in the construction industry, International Journal of Construction Management, 21(4): 337-352. https://doi.org/10.1080/15623599.2018.1536964.

Makkar, S. and Basu, S. (2019). The impact of emotional intelligence on workplace behaviour: a study of bank employees. Global Business Review, 20(2): 458478. https://doi.org/10.1177/0972150917713903.

Melik, J. (2012). China: The paradox of foreign education. BBC News, 2 August.

Miao, C., Humphrey, R.H. and Qian, S. (2018). A cross-cultural meta-analysis of how leader emotional intelligence influences subordinate task performance and organizational citizenship behaviour. Journal of World Business, 53(4): 463-474. https://doi.org/10.1016/j.jwb.2018.01.003.

Mok, K.H., Han, X., Jiang, J. and Zhang, X. (2017). International and transnational learning in higher education: A study of students' career development in China. London: Centre for Global Higher Education.

National Bureau of Statistics of China (2017). China Statistical Yearbook 2017. Beijing: National Bureau of Statistics of China.

O'Boyle, E.H., Humphrey, R.H., Pollack, J.M., Hawver, T.H. and Story, P.A. (2011). The relation between emotional intelligence and job performance: A metaanalysis. Journal of Organizational Behaviour, 32(5): 788-818. https://doi.org/ 10.1002/job.714.

Othman, A.A.E. (2014). A study of the competency requirements of property development graduates to meet the qualifications of the South African construction industry. Journal of Engineering, Design and Technology, 12(1): 2-28. https://doi.org/10.1108/JEDT-04-2012-0019.

Pant, I. and Baroudi, B. (2008). Project management education: The human skills imperative. International Journal of Project Management, 26(2): 124-128. https://doi.org/10.1016/j.jproman.2007.05.010.

Poon, J. (2017). Relationships between demographic factors and employment prospects of architecture, construction and urban planning graduates. International Journal of Construction Education and Research, 13(2): 83-101. https://doi.org/10.1080/15578771.2016.1153008.

(2012). Real estate graduates' employability skills: The perspective of human resource managers of surveying firms. Property Management, 30(5): 416-434. https://doi.org/10.1108/02637471211273392.

Raghubir, A.E. (2018). Emotional intelligence in professional nursing practice: A concept review using Rodgers's evolutionary analysis approach. International Journal of Nursing Sciences, 5(2): 126-130. https://doi.org/10 .1016/j.ijnss.2018.03.004.

Robbins, S.P. and Hunsaker, P.L. (2008). Training in Interpersonal Skills: Tips for Managing People at Work. 3rd Ed. Upper Saddle River, NJ: Prentice Hall.

Robles, M.M. (2012). Executive perceptions of the top 10 soft skills needed in today's workplace. Business Communication Quarterly, 75(4): 453-465. https://doi. org/10.1177/1080569912460400.

Schutte, N.S. and Loi, N.M. (2014). Connections between emotional intelligence and workplace flourishing. Personality and Individual Differences, 66: 134-139. https://doi.org/10.1016/j.paid.2014.03.031. 
Sharma, T. and Singh, S. (2018). Relationship of emotional intelligence with cultural intelligence and change readiness of Indian managers in the service sector. Journal of Organizational Change Management, Vol. ahead-of-print No. ahead-of-print. https://doi.org/10.1108/JOCM-05-2017-0193.

Stevens, M.J. and Campion, M.A. (1994). The knowledge, skill and ability requirements for teamwork: Implications for human resource management. Journal of Management, 20(2): 503-530. https://doi.org/10.1177/014920639402000210.

Su, W. and Zhang, M. (2015). An integrative model for measuring graduates' employability skills: A study in China. Cogent Business and Management, 2(1): 1060729. https://doi.org/10.1080/23311975.2015.1060729.

Sunindijo, R.Y. (2012). Integrating emotional intelligence, political skill and transformational leadership in construction. Civil Engineering Dimension, 14(3): 182-189. https://doi.org/10.9744/ced.14.3.182-189.

Sunindijo, R.Y. and Hadikusumo, B.H.W. (2014). Emotional intelligence for managing conflicts in the sociocultural norms of the Thai construction industry. Journal of Management in Engineering, 30(6): 04014025. https://doi.org/10 .1061/(ASCE)ME.1943-5479.0000211.

Sunindijo, R.Y., Zou, P.X.W. and Dainty, A.R.J. (2017). Managerial skills for managing construction safety. Civil Engineering Dimensions, 19(2): 63-72. https://doi .org/10.9744/ced.19.2.63-72.

Yang, R. and Welch, A. (2012). A world-class university in China? The case of Tsinghua. Higher Education, 63(5): 645-666. https://doi.org/10.1007/s10734-011-9465-4. 